\title{
LED ENHANCEMENT IN MITOCHONDRIAL OXIDATIVE PHOSPHORYLATION FOR HEPATECTOMIZED RATS ${ }^{1}$
}

\author{
Orlando de Castro-e-Silva $\mathbf{J r}^{2}$ \\ Tiago Castro-e-Silva ${ }^{3}$ \\ Fernando Silva Ramalho ${ }^{4}$ \\ Leandra Naira Zambelli Ramalho ${ }^{5}$ \\ Sergio Zucoloto ${ }^{6}$ \\ Luis Gustavo Marcassa ${ }^{7}$ \\ Vanderlei Salvador Bagnato ${ }^{8}$
}

\begin{abstract}
Recently, the LED (light emitting diode) developed by the Optics Group of IFSC-USP has been used instead of laser for the treatment of skin tumors by the PDT (Photodinamic Therapy) because of its low operational cost compared to the use of a laser. In this paper we investigate the effect of LED light on oxidative phosphorylation during liver regeneration after partial hepatectomy. Twenty-four male Wistar rats $(250 \mathrm{~g})$ were kept in identical housing units on a 12-hour light/12 hour dark cycle. The LED 10 group was exposed to LED at $638 \mathrm{~nm}\left(10 \mathrm{~J} / \mathrm{cm}^{2}\right.$ for 3 minutes $)$. Seventy percent partial hepatectomy was performed in the LED 10 and HPC (Partial Hepatectomy-Control). A sham-operated group (C) was used for control. Twenty four hours after the procedure, LED 10, HPC and control animals were sacrificed. Samples of liver tissue were used for the mitochondrial respiration assay. Statistical comparisons of the groups were performed by analysis of variance (ANOVA), followed by the Bonferroni post-test. Probability values less than 0.05 were considered to be statistically significant. the phosphorylation index (FI) for the LED 10 group was higher than that for the HPC group and for the sham group $(p<005)$. The FI for the HPC group was higher than that for the sham group $(\mathrm{p}<005)$. The values of the ADP:O ratio for the three groups, which did not differ significantly from one another $(p>0.05)$. In the
\end{abstract}

present study we noted an effective interaction between LED light and hepatic mitochondria, with an increased phosphorylation rate for the latter. Available from: URL: http://www.scielo.br/acb

Key Words - Liver; mitochondrial function; phosphorylation index; partial hepatectomy.

\section{INTRODUCTION}

Many studies have demonstrated that laser light modifies cell metabolism. ${ }^{1,2,3}$ Both visible red light an infrared light have been shown to present many different effects at the cellular level. Light radiation must be absorbed $^{4}$ to promote a biological response; on this basis, we expected any type of light therapy to be an effect of light itself, and not a function of coherency which is a unique property of laser light. ${ }^{2,5}$ Thus, almost monochromatic light is expected to present effects similar to those of laser. With this in mind, we performed a series of experiments to demonstrate that the effects of low energy laser therapy are due to the effects of light and not to the unique properties of

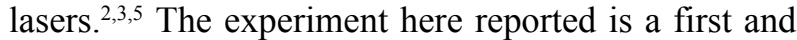
involves the observation of variations of respiratory cell function after irradiation with a light emitting diode (LED). Recently, the LED developed by the Optics Group of IFSC-USP has been used instead of laser for the treatment of skin tumors by the PDT (Photodinamic

1 Work performed at Faculdade de Medicina de Ribeirão Preto, Universidade de São Paulo, Ribeirão Preto, São Paulo, and Instituto de Física de São Carlos - Universidade de São Paulo -São Carlos - São Paulo - Brazil

2 Associate Professor, Department of Surgery and Anatomy of FMRP-USP

3 Undergraduate studant of IFSC- USP

4 Professor Doctor of Department of Surgery and Anatomy of FMRP-USP

5 Professor Doctor of Department of Patology of FMRP-USP

6 Full Professor of Department of Patology of FMRP-USP

7 Associate Professor of IFSC- USP

8 Full Professor of IFSC- USP 
Therapy) (an effect not previously tested by other investigators) because of its low operational cost compared to the use of a laser. In this paper we investigate the effect of LED light on oxidative phosphorylation during liver regeneration after partial hepatectomy.

\section{METHODS}

\section{Animals}

Twenty-four male Wistar rats weighing $250 \mathrm{~g}$ were obtained from the Central Animal House of the University of São Paulo, Ribeirão Preto, Brazil. The animals received standard laboratory chow (Purina) and water ad libitum, and were kept in identical housing units on a 12-hour light/12 hour dark cycle. The LED 10 group was exposed to LED at $638 \mathrm{~nm}\left(10 \mathrm{~J} / \mathrm{cm}^{2}\right.$ for 3 minutes). Seventy percent partial hepatectomy was performed by the method of Higgins \& Anderson ${ }^{6}$ in the LED 10 and HPC (Partial Hepatectomy-Control). A sham-operated group (C) was used for control.

On the basis of a previous study by our group, 5,7 24 hours after the procedure, LED 10, HPC and control animals were sacrificed under diethyl ether anesthesia. Samples of liver tissue were used for the respiration assay.

\section{Isolation of Liver Mitochondria ${ }^{8}$}

Mitochondria were isolated by conventional differential centrifugation. Fragments of liver tissue were washed in cold saline and homogenized three times at 1 min intervals in a Potter-Elvehjem homogenizer in $10 \mathrm{~mL}$ of a medium containing $250 \mathrm{mM}$ sucrose, 1 mM EGTA, and $10 \mathrm{mM}$ Hepes-KOH, pH 7.2. Homogenates were centrifuged at $770 \mathrm{~g}$ for $5 \mathrm{~min}$ and the resulting supernatant was further centrifuged at $9800 \mathrm{~g}$ for $10 \mathrm{~min}$. Pellets were suspended in $10 \mathrm{~mL}$ of a medium containing $250 \mathrm{mM}$ sucrose, $0.3 \mathrm{mM}$ EGTA

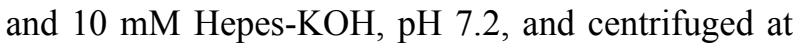
$4500 \mathrm{~g}$ for $15 \mathrm{~min}$. The final mitochondrial pellet was suspended in $0.5 \mathrm{ml}$ of a medium containing $250 \mathrm{mM}$ sucrose and $10 \mathrm{mM}$ Hepes-KOH, $\mathrm{pH}$ 7.2. All procedures were conducted at $4{ }^{\circ} \mathrm{C}$ and all solutions were prepared using glass-distilled and deionized water.

\section{Mitochondrial Respiration ${ }^{9}$}

Mitochondrial respiration was monitored polarographically with an oxygraph equipped with a Clark-type oxygen electrode (IFSC-USP). Assays were performed at $30^{\circ} \mathrm{C}$ using mitochondria energized with
$5 \mathrm{mM}$ potassium succinate. Respiration media contained $125 \mathrm{mM}$ sucrose, $65 \mathrm{mM} \mathrm{KCl}, 0.1 \mathrm{mM}$ EGTA, $1 \mathrm{mM}$ $\mathrm{MgCl}_{2}, 2 \mathrm{mM} \mathrm{KH}_{2} \mathrm{PO}_{4}$, and $10 \mathrm{mM}$ Hepes-KOH, $\mathrm{pH}$ 7.4. The state III of mitochondrial respiration was determined after the addition of $400 \mathrm{nmol}$ of ADP and state IV (basal) was determined after phosphorylation of ADP addition. Both states are expressed as $\mathrm{n}$ atoms of $\mathrm{O}_{2} / \mathrm{min} / \mathrm{mg}$ of protein. The ratio between the state III and IV rates (ratio of respiration control, RCR) was determined and represents the coupling of the mitochondria to the medium. Mitochondrial protein content was determined by the biuret reaction.

\section{Statistical analysis}

Data are reported as mean \pm SEM. Statistical comparisons of the groups were performed by analysis of variance (ANOVA) for parametric measurements, followed by the Bonferroni post-test. Probability values less than 0.05 were considered to be statistically significant.

\section{RESULTS}

As shown in figure 1, the phosphorylation index (FI) (mean $+\mathrm{SD})$ for the LED 10 group was higher than that for the HPC group and for the sham group $(p<005)$. The FI for the HPC group was higher than that for the sham group $(\mathrm{p}<005)$.

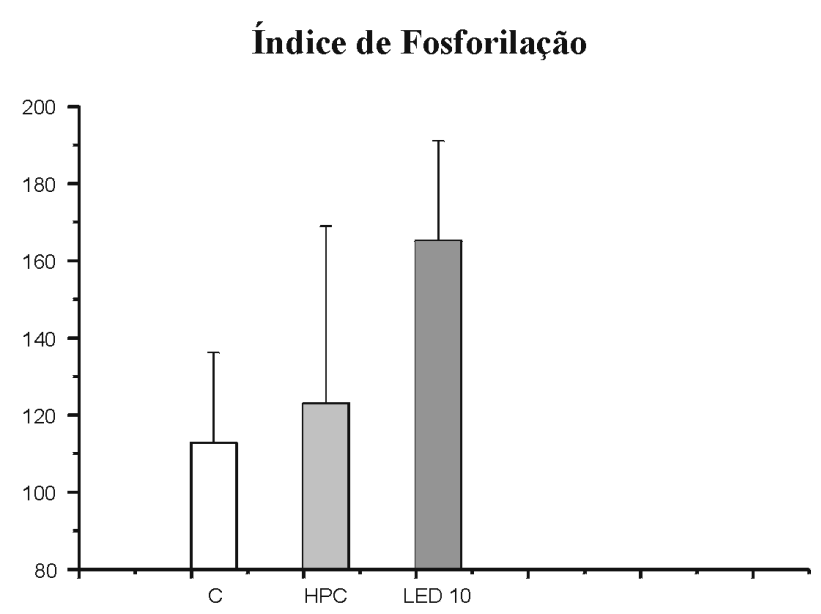

Figure 1 - Phosphorylation Index in the groups Control (C), Partial Hepatectomy- control (HPC) and HPC and Led.

Figure 2 shows the values of the ADP:O ratio (mean $+\mathrm{SD}$ ) for the three groups, which did not differ significantly from one another $(p>0.05)$. 


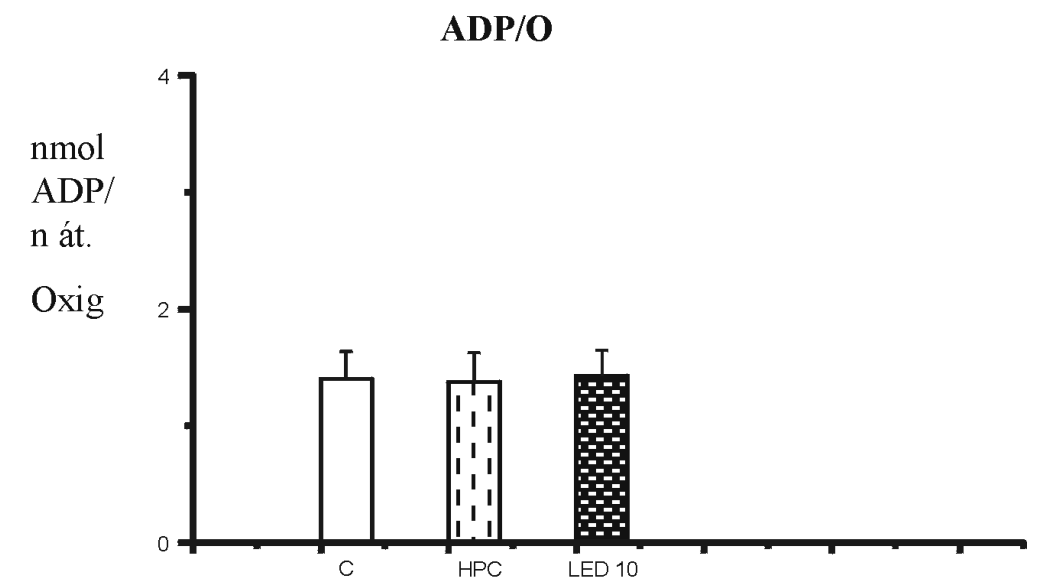

Figure 2 - ADP/O index in the groups Control (C), Partial Hepatectomycontrol (HPC ) and HPC and Led

Figure 3 shows the LED-based device emitting red light at an emission peak at $626 \mathrm{~nm}$.

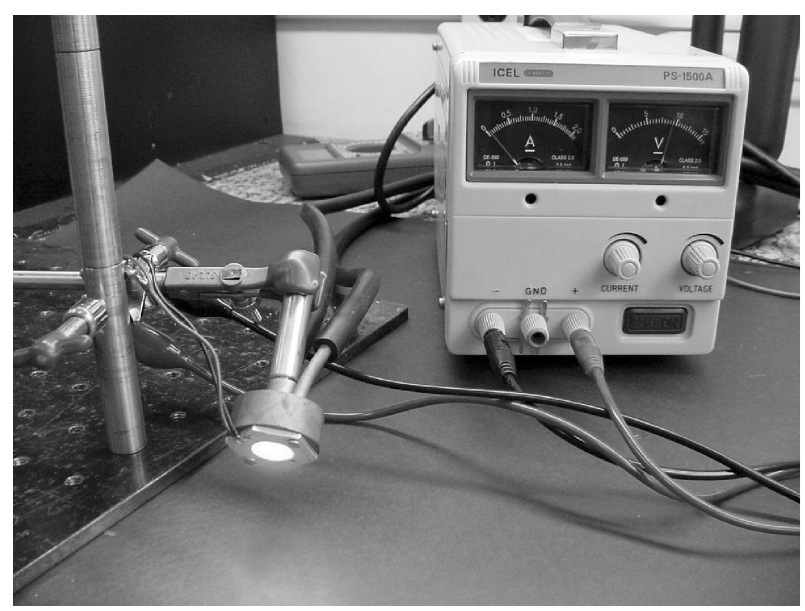

Figure 3 - LED-based device emitting red light at an emission peak at $626 \mathrm{~nm}$.

\section{DISCUSSION}

Previous studies from our laboratory have shown an increase in the energy capacity and hepatic regeneration of hepatic remnants illuminated with low intensity laser light at all wavelengths used. ${ }^{5,10}$ Laser light is a coherent light with a specific wavelength that effectively stimulates mitochondrial function. ${ }^{2,5,10}$ In the present study we investigated the effect of low intensity LED light on mitochondrial function through the oxidative phosphorylation index. LEDs and lasers both produce radiation at specific wavelength. Nevertheless, LEDs are neither coherent nor collimated and they are broader in emission when compared with lasers. These properties can cause higher penetration in many cases.
We have used a special home-made LED device that employs an array of emitting centers, with wavelength centered at $630 \mathrm{~nm}$. The overall emitted powers over a full hemisphere is about $500 \mathrm{~mW}$, given an energy density that depends on the distance between device and target. Intensities as 20 to $50 \mathrm{~mW} / \mathrm{cm}^{2}$ are obtained with this device.

In the present study we noted an effective interaction between LED light and hepatic mitochondria, with an increased phosphorylation rate for the latter. This increase occurred at levels similar to those induced by laser light, indicating a possible effect of hepatic regeneration induction, an energydependent process. ${ }^{2,5,10}$

The ADP:O ratio was similar in the three groups studied, showing that LED light did not have a damaging effect on the mitochondrial membrane. ${ }^{11}$ Thus, the light induced an increase in oxidative phosphorylation without damaging the mitochondrial membrane. Further studies are currently underway in our laboratory for a better understanding of the interaction between LED light and hepatic cells and organelles for clinical application to hepatology in the near future.

\section{REFERENCES}

1. Castro e Silva Jr. O, Menegazzo LAG, Granato RG, Bagnato VS, Zílio S, Zucoloto S. Luz Laser e Tecidos Biológicos. da Experimentação à Aplicação Clínica. Estudo Atual e Perspectivas. Acta Cirúrgica Brasileira 1997;12 supl 1: 34-6.

2. Souza Jr. EM, Brunetti AM, Bagnato VS, Viaro F, Souza MEJ, Castro e Silva Jr. O. Efeito da Luz Laser e Luz Convencional sobre o Metabolismo Energético de Fígados de Ratos. Acta Cirúrgica Brasileira 1997;12, supl 1:22-3.

3. Lima AALA, Melo CAS, Brasil IRC, Ramalho LNZ, Zucoloto S, Bagnato VS, Castro e Silva Jr.,, O. Efeito do Laser sobre a Cirrose Hepática. Acta Cirúrgica Brasileira 2000;15, supl.2:21-2. 
4. Melo CAS, Lima AALA, Brasil IRC, Castro e Silva Jr. O, Magalhães DV, Marcassa LG, Bagnato VS. Characterization of light penetration in rat tissues. J Clin Laser Med Surg 2001; 175-9.

5. Castro e Silva Jr. O, Zucoloto S, Menegazzo LAG, Granato RG, Marcassa LG, Bagnato VS. Laser enhacement in hepatic regeneration for partially hepatectomized rats. Lasers Surg Med 2001;29:73-7.

6. Higgins GM, Anderson RM. Experimental pathology of the liver: I. Restoration of the liver of the white rat following partial surgical removal. Arch Pathol 1931;12:186-202.

7. Ramalho FS, Ramalho LNZ, Castro e Silva Jr. O, Zucoloto S, Corrêa FMA. Effect of angiotensin-converting enzyme inhibitors on liver regeneration in rats. Hepatogastroenterol 2002;49:1347-51.

8. Souza MEJ Polizello, A. C. M.; Uyemura, S. A.; Castro e Silva Jr, O.; Curti, C. Effect of fluoxetine on rat liver mitochondria. Biochem Pharmacol 1994,48:535-41.

9. Chance, B.; Williams, G. R.;. Respiration enzymes in oxidative phosphorylation. III. The steady state. J Biol Chem 1956;217: 409-27.
10. Castro e Silva Jr. O,, Zucoloto S, Marcassa LG, Marcassa J, Kurachi C, Melo CAC, Ramalho FS, Ramalho LNZ, Bagnato VS. Spectral response for laser enhacement in hepatic regeneration for partially hepatectomized rats. Lasers Surg Med 2002;30: in press.

11. Curti C, Uyemura SA. Estudos da fosforilação oxidativa. In: Castro e Silva Jr., O.; Zucoloto, S.; Beer Jr., A. Modelos experimentais de pesquisa em cirurgia. São Paulo: Robe Editorial; 1998, p: 149-158.

\section{Endereço para Correspondência}

Orlando de Castro e Silva Jr

Departamento de Cirurgia e Anatomia

Faculdade de Medicina de Ribeirão Preto - USP

Campus Universitário - Monte Alegre

14049-990 - Ribeirão Preto - SP

e-mail-orlandocjs@hotmail.com

Conflito de interesse: nenhum

Fonte de Financiamento: FAPESP 